\title{
ICT-121 Dendritic Cell Vaccine
}

National Cancer Institute

\section{Source}

National Cancer Institute. ICT-121 Dendritic Cell Vaccine. NCI Thesaurus. Code C124652.

A cell-based cancer vaccine composed of autologous dendritic cells (DCs) pulsed with purified peptides derived from the tumor-associated antigen (TAA) CD133, with potential immunostimulatory and antineoplastic activities. Upon leukapheresis, monocytes are differentiated into DCs and are mixed with the CD133 peptides. Upon intradermal readministration of the ICT-121 DC vaccine, the DCs present the CD133 peptides to the immune system, which stimulates the immune system to induce a specific cytotoxic $T$ lymphocyte $(C T L)$ response against CD133-expressing tumor cells and leads to tumor cell lysis. CD133 is overexpressed on various types of cancer cells; its overexpression is correlated with increased resistance to chemotherapy. 